\title{
Children's health and parental socioeconomic factors: a population-based survey in Finland
}

\author{
Sanna M Siponen ${ }^{1 *}$, Riitta S Ahonen ${ }^{1+}$, Piia H Savolainen ${ }^{1 \dagger}$ and Katri P Hämeen-Anttila ${ }^{2 \dagger}$
}

\begin{abstract}
Background: Socioeconomic inequalities in health are a global problem, not only among the adult population but also among children. However, studies concerning young children especially are rare. The aim of this study was to describe the health of Finnish children under 12 years of age, and the socioeconomic factors associated with health. The socioeconomic factors were parental education level, household net income, and working status.

Methods: A population-based survey among Finnish children aged under 12 years $(n=6,000)$ was conducted in spring 2007. A questionnaire was sent to parents, and a response rate of $67 \%$ was achieved. Each child's health was explored by asking a parent to report the child's health status on a 5-point Likert scale, current symptoms from a symptoms list, and current disease(s) diagnosed by a physician. The final three outcome measures were poor health, the prevalences of psychosomatic symptoms, and long-term diseases. Data were analysed using Pearson's Chi-Square tests, and logistic regression analysis with 95\% confidence intervals (Cls). P-values $\leq 0.05$ were considered as statistically significant.
\end{abstract}

Results: In total, 3\% of parents reported that their child's health status was poor. The prevalences of psychosomatic symptoms and long-term diseases were both $11 \%$. The probability for poor health status was lowest among children aged 3-6 and 7-11 years, and for psychosomatic symptoms among 3-6-year-old children, whereas the odds ratios for long-term diseases was highest among children aged 7-11 years. Parental socioeconomic factors were not associated with the children's health.

Conclusions: Most of the children were reported by their parent to have good health status, and approximately one tenth had experienced some psychosomatic symptoms or long-term diseases. Our study suggests that parental socioeconomic factors are not associated with the health of children aged under 12 years in Finland.

Keywords: child, health, socioeconomic factors, population-based study

\section{Background}

Increasing morbidity and socioeconomic health inequalities are a global problem [1,2]. European studies have shown that low socioeconomic status, low education and low income are associated with poor health among adult populations, e.g., poor self-assessed health, mortality, prevalence of long-term diseases, and the experience of psychosomatic symptoms [3-9]. Inequalities between population groups have increased in Europe [1], including Finland [3,7], even though general well-being and living conditions have improved in recent decades [4].

\footnotetext{
* Correspondence: sanna.siponen@uef.fi

† Contributed equally

'School of Pharmacy/Social Pharmacy, University of Eastern Finland, P.O. Box 1627, FIN-70211 Kuopio, Finland

Full list of author information is available at the end of the article
}

Minimising health inequalities between population groups has been an objective of health policy in several European countries [1,4].

A relationship between parental socioeconomic factors and health has also been demonstrated among children. For example, parents' low education, unemployment, and low income have been associated with poor health status and an increased prevalence of chronic diseases and psychosomatic symptoms [10-19]. In addition, the presence of multiple parental socioeconomic risk factors may have a cumulative effect on children's poor health $[14,18,20]$.

The association of low socioeconomic background and poor health is not simple. Many environmental and social factors, such as poor nutrition and poor access to

\section{Biomed Central}


health care, have been found to be associated with low socioeconomic background, e.g. low income and education, and thus with poor health and development of children [21-23]. Low education, young age and depressive symptoms of a caregiver have also been associated with poor nutrition of children, and children in such families have been found to be at developmental risk [23]. Low socioeconomic background of parents may also lead to a poor relationship with children and thereby affect their health over a longer period [22].

Some studies have reported an inverse association between parental socioeconomic status and child health. For example, in Finland the prevalence of long-term diseases among children, especially asthma and allergies, was found to be slightly higher in families with a highly educated mother than in families with a less educated mother [24]. In contrast, family income was not associated with long-term diseases among children. An increased number of diseases diagnosed by a physician and colds among children with highly educated parents have been reported in West Germany [25], and in the United States for respiratory conditions [16]. In addition, a similar relationship between parental occupation and psychosomatic symptoms has been found in Scotland, especially among girls [26].

Age dependency in health inequalities have also been a point of interest for several researchers $[16,17,26]$. On the basis of equalization theory it has been hypothesized that health inequalities are more evident in childhood, and diminish in adolescence [26]. However, this is not supported by the results of other studies $[10,13,16,17,26]$. In fact, it remains unclear whether parental socioeconomic background is associated with children's health at different ages.

Clarifying the association of parental socioeconomic background and children's health is important since it has been shown that health inequalities in childhood predict poor health in adulthood $[27,28]$. Most of the studies have focused on health as self-reported by the parent $[12,14,17]$, the prevalence of long-term diseases [24], physical and psychosomatic symptoms [27], or combinations of these $[10,11,13,15,16]$. Studies have focused mainly on children under 18 years of age as one homogenous group $[11,14,16,18-20]$, and a few on children over 10 years of age $[26,29]$. Only a few studies have focused on children aged under 18 years by using different age groups $[10,13,17]$. To our knowledge, studies using three dimensions (self-reported health, prevalence of long-term diseases, and psychosomatic symptoms) are rare [26], especially among young children.

The aim of this study was to describe the health of Finnish children aged under 12 years, and socioeconomic factors associated with health. The socioeconomic factors were parental education level, household net income, and working status.

\section{Methods \\ Context \\ Socioeconomic characteristics in Finland}

In 2007, when this study was conducted, there were about 5.3 million inhabitants in Finland, of whom 17\% ( $\mathrm{n}=894,590)$ were children under 15 years of age (Statistics Finland, http://www.stat.fi/). Seventy percent of 15-64-year-old people were working and 6\% were unemployed. In addition, $65 \%$ of those aged over 14 years had some educational qualification obtained after primary school, mostly in senior high school or vocational school (11-13 years of education) (39\%). Polytechnic, college or university degrees ( $\geq 15$ years of education) had been completed by $26 \%$ of the population. Furthermore, $14 \%$ of the total population were in the low-income group, living below $60 \%$ of the median income level $(€ 13,600 /$ year/one-person-household in 2007). Being in the lowincome group was most common among people who were unemployed, students, or retired.

\section{Health care in Finland}

In Finland, primary health care is available for all citizens for a small fee. In addition, special health care is offered in 20 hospital districts. The primary and special health care systems are complemented by private health care, and a part of the fees are reimbursed by the Social Insurance Institution.

The Finnish government provides up to 9 months paid maternity leave [30]. Partial support from the government is also provided for up to three years, if a parent wishes to take care of a child at home. Children's health is monitored regularly, free of charge, in child welfare clinics and in the school health care system until the end of primary school (Decision of the Council of State 380/2009). More information about the health care system in Finland may be found on the websites of the Social Insurance Institution (http://www.kela.fi) and the Ministry of Social Affairs and Health (http://www. stm.fi).

\section{Data collection}

We carried out a population-based survey among Finnish children aged under 12 years in spring (FebruaryApril) 2007. The study sample consisted of 6,000 Finnish children living in Finland in December 2006, and they were randomly selected from the Finnish National Population Register Centre, excluding children in institutional care.

Data were collected using a structured questionnaire consisting of 30 questions about background information, health status, and the use of medicine by the child (Additional File 1 Additional File 2). Furthermore, 
questions regarding information sources about medicines and background information about the respondent were included. The questions about children's health were designed to be consistent with questions used in previous population-based studies conducted in Finland $[3,31]$, and with the school health surveys among children aged 14-18 years which are conducted biennially [32]. The questionnaire was available in Finnish and Swedish, both of which are official languages in Finland, and it was first pilot-tested for face-validity among a convenience sample of 61 mothers. Minor modifications were made based on the pilot.

The questionnaire was sent to parents, primarily to mothers, but it was addressed to the parent who usually takes care of the child's medication. The child's name was printed on the questionnaire to indicate the child that was selected from the study population. This was important in families with more than one child. Two reminders were sent. After the questionnaires were returned, the child's name was removed and a random number was assigned to each questionnaire to ensure the anonymity of the respondent. This was ensured by following national and local instructions for researchers (National Advisory Board on Ethics: http://www.tenk.fi/ ENG/function.htm). A more detailed description of the study sample and data collection is presented elsewhere [33].

\section{Outcomes}

The main outcomes of this study were poor health among children, and the prevalence of psychosomatic symptoms and long-term diseases.

Health status was determined by asking a parent to report the current health status of their child using the following categories: good, fairly good, moderate, fairly poor and poor. For the purpose of the data analysis, categories were combined as "moderate or poor" (including moderate $\mathrm{n}=106$, fairly poor $\mathrm{n}=25$ and poor $\mathrm{n}=4$ ), and as "good" (including fairly good $\mathrm{n}=$ 631 and $\operatorname{good} n=3,249)$.

The prevalence of psychosomatic symptoms was measured via a list of symptoms (described in Table 1). Parents were asked to circle "yes" or "no" whether their child currently experienced that symptom. They could also select "don't know" or report other symptoms if they were not in the list. In the symptoms list, sleep disorders, fatigue or dizziness, anxiety and depression were considered to be psychosomatic symptoms. Most of the children who had experienced psychosomatic symptoms had experienced one psychosomatic symptom ( $8 \%$ of children), and only $3 \%$ of children had experienced two psychosomatic symptoms or more. Thus, the final outcome included children who had experienced one or more psychosomatic symptoms.
The prevalence of long-term diseases was explored by asking the parent to write down any diseases or injuries which had been diagnosed by a physician that their child currently had. Of those diseases reported by parents (shown in Table 2), asthma, allergy, epilepsy, diabetes, lactose intolerance, migraine, attention deficit hyperactivity disorder (ADHD), heart defect, atopy, rheumatoid arthritis, and celiac disease were considered long-term diseases. The majority of children with a long-term disease had one long-term disease ( $9 \%$ of children), and $2 \%$ of children had two or more longterm diseases. Therefore, the final outcome included children who had one or more long-term diseases.

Parental socioeconomic factors were measured by asking the parent who completed the questionnaire to report their highest educational level from a 7-item list, and household net income per month $(€)$ from an 11items list (scale: under $€ 500$ to over $€ 10,000$ ). For the analysis, the highest educational level and household net income per month were categorized as shown in Table 3. Working status of a parent was classified as "Working" and "Not in work" (including unemployed parents, home with children, retired, studying, or on sick leave), which also made it possible to avoid multicollinearity with the household net income.

\section{Statistical analysis}

Data were analyzed with SPSS for Windows, Version 14.0 (SPSS Inc., Chigaco, IL, USA). The results are presented using descriptive statistics: frequencies, percentages and cross-tabulation. Pearson's Chi-Square test was used when exploring the association between categorical variables. A p-value of $\leq 0.05$ was considered to be statistically significant. Three age groups of children (0-2, 3-6 and 7-11 years) were used in analyses, as in previous population-based studies conducted in Finland [31]. Logistic regression analyses were conducted when measuring the association between parental socioeconomic background and the child's health. The results are presented as odds ratios (ORs) together with their 95\% confidence intervals (CIs).

The discriminating ability of the logistic regression model was measured with ROC analysis, which showed the discriminating ability of the model to be excellent for poor health (AUROC value 0.901), moderate for psychosomatic symptoms (0.742), and adequate for longterm diseases (0.675). The interaction between age and gender was also measured but no significant results were found. Thus, the interaction variable of age and gender was not included in the analysis.

\section{Results}

The final study population consisted of 5,992 children, because the parents of 8 children were not reached by 
Table 1 Current symptoms experienced by children as reported by the parent

\begin{tabular}{|c|c|c|c|c|c|c|c|}
\hline Symptoms & Boys & & & Girls & & & Total \\
\hline & $0-2$ & $3-6$ & $7-11$ & $0-2$ & $3-6$ & $7-11$ & \\
\hline & $(n=532)$ & $(n=677)$ & $(n=865)$ & $(n=468)$ & $(n=595)$ & $(n=847)$ & $(n=3984)$ \\
\hline & n (\%) & n (\%) & n (\%) & n (\%) & n (\%) & n (\%) & n (\%) \\
\hline Psychosomatic symptoms & $66(12.4)$ & $50(7.4)$ & $104(12.0)$ & $67(14.3)$ & $47(7.9)$ & $103(12.2)$ & $437(10.9)$ \\
\hline Sleep disorders & $50(9.4)$ & $26(3.8)$ & $29(3.4)$ & $54(11.5)$ & $23(3.9)$ & $26(3.1)$ & $218(5.5)$ \\
\hline Fatigue or dizziness & $24(4.5)$ & $21(3.1)$ & $50(5.8)$ & $21(4.9)$ & $19(3.2)$ & $61(7.2)$ & $196(4.9)$ \\
\hline Anxiety & $3(0.6)$ & $12(1.8)$ & $43(5.0)$ & $7(1.5)$ & $12(2.0)$ & $37(4.4)$ & $114(2.9)$ \\
\hline Depression & $0(0)$ & $3(0.4)$ & $16(1.8)$ & $1(0.2)$ & $4(0.7)$ & $11(1.3)$ & $35(0.9)$ \\
\hline Other symptoms & $382(71.8)$ & $421(62.2)$ & $507(58.6)$ & $318(67.9)$ & $386(64.9)$ & $551(65.1)$ & $2565(64.4)$ \\
\hline Symptoms of common cold & $244(45.9)$ & $255(37.7)$ & $222(25.7)$ & $190(40.6)$ & $209(35.1)$ & $224(26.4)$ & $1344(33.7)$ \\
\hline Eczema & $156(29.3)$ & $143(21.1)$ & $163(18.8)$ & $135(28.8)$ & $170(28.6)$ & $181(21.4)$ & $948(23.8)$ \\
\hline Flatulence & $67(12.6)$ & $54(7.8)$ & $110(12.7)$ & $48(10.3)$ & $47(7.9)$ & $128(15.1)$ & $454(11.4)$ \\
\hline Growing pains & $11(2.1)$ & $78(11.5)$ & $98(11.3)$ & $4(0.9)$ & $57(9.6)$ & $108(12.8)$ & $356(8.9)$ \\
\hline Sore throat & $20(3.8)$ & $25(3.7)$ & $55(6.4)$ & $7(1.5)$ & $38(6.4)$ & $72(8.5)$ & $217(5.4)$ \\
\hline Headache & $1(0.2)$ & $19(2.8)$ & $71(8.2)$ & $1(0.2)$ & $12(2.0)$ & $102(12.0)$ & $206(5.2)$ \\
\hline Fever & $32(6.0)$ & $31(4.6)$ & $23(2.6)$ & $31(6.6)$ & $25(4.2)$ & $13(1.5)$ & $155(3.9)$ \\
\hline Allergy symptoms & $15(2.8)$ & $19(2.8)$ & $42(4.9)$ & $15(3.2)$ & $15(2.5)$ & $38(4.5)$ & $144(3.6)$ \\
\hline Constipation & $24(4.5)$ & $23(3.4)$ & $16(1.8)$ & $25(5.3)$ & $21(3.5)$ & $25(3.0)$ & $134(3.4)$ \\
\hline Earache & $37(7.0)$ & $21(3.1)$ & $12(1.4)$ & $20(4.3)$ & $21(3.5)$ & $17(2.0)$ & $128(3.2)$ \\
\hline Pain in neck or shoulders & $0(0)$ & $5(0.7)$ & $26(3.0)$ & $0(0)$ & $2(0.3)$ & $50(5.9)$ & $83(2.1)$ \\
\hline Diarrhoea & $16(3.0)$ & $12(1.8)$ & $4(0.5)$ & $14(3.0)$ & $6(1.0)$ & $7(0.8)$ & $59(1.5)$ \\
\hline Stomach flu & $9(1.7)$ & $11(1.6)$ & $5(0.6)$ & $9(1.9)$ & $4(0.7)$ & $6(0.7)$ & $44(1.1)$ \\
\hline Low back pain & $0(0)$ & $6(0.9)$ & $10(1.2)$ & $0(0)$ & $0(0)$ & $16(1.9)$ & $32(0.8)$ \\
\hline Other symptoms* & $42(7.9)$ & $46(6.8)$ & $72(8.3)$ & $31(6.6)$ & $49(8.2)$ & $88(10.4)$ & $328(8.2)$ \\
\hline
\end{tabular}

${ }^{*}$ e.g. other stomach symptoms and other symptoms of pain.

mail. We received 4,121 completed questionnaires. Eighty-nine questionnaires were excluded because they were completed for another child than the child included in the study sample. Thus, the final study sample was 4,032 (response rate 67\%). The respondent was mainly the mother (in 95\% of cases) and secondly the father (in $4 \%$ of cases). We analysed the representativeness of the study population and non-respondents, which showed that the study population was representative of the target population in respect of age and gender. A more specific analysis of the representativeness of the study population is available elsewhere [34].

The characteristics of the study population are shown in Table 3. Most parents reported that their child had good health, while moderate or poor health status was reported for $3 \%$ of the children. The prevalences of psychosomatic symptoms (11\%) and long-term diseases (11\%) were equal. Of the socioeconomic factors, most of the parents $(61 \%)$ had senior high school or vocational school (11-13 years) as their highest educational background, and the majority of the parents were working (63\% of parents). Most parents had $€ 2,000-2,999$ (32\% of parents) or $€ 3,000-3,999$ (35\%) as their household net income per month.
Tables 1 and 2 show the symptoms children had experienced, and the diseases diagnosed by a physician, according to age and gender. Symptoms of the common cold and eczema were the most prevalent symptoms among the children (34\% and $24 \%$ of children, respectively), and especially among children aged 0-2 years (Table 1 ). Boys were more likely to have experienced symptoms of the common cold at this age than girls ( $46 \%$ of boys and $41 \%$ of girls), but the symptoms of eczema were equally common among both genders. Sleep disorders were the most commonly reported psychosomatic symptoms ( $6 \%$ of children), and they were most prevalent among children aged $0-2$ years $(9 \%$ of boys and $12 \%$ of girls), decreasing with age. In contrast, the most common diseases diagnosed by a physician were allergy ( $4 \%$ of children) and asthma (4\%) (Table 2). These were also the most common long-term diseases. The prevalence of these long-term diseases increased with age, and they were nearly equally common among boys and girls at 7-11 years of age.

Of the factors measured, age was found to be associated with poor health status, prevalence of psychosomatic symptoms, and long-term diseases (Table 3). Of the socioeconomic factors, parents' education level or 
Table 2 Children's diseases diagnosed by a physician, as reported by the parent

\begin{tabular}{|c|c|c|c|c|c|c|c|}
\hline Diseases & Boys & & & Girls & & & Total \\
\hline & $0-2$ & $3-6$ & $7-11$ & $0-2$ & $3-6$ & $7-11$ & \\
\hline & $\begin{array}{c}(\mathrm{n}=532) \\
\mathrm{n}(\%)\end{array}$ & $\begin{array}{c}(\mathrm{n}=680) \\
\mathrm{n}(\%)\end{array}$ & $\begin{array}{c}(n=879) \\
n(\%)\end{array}$ & $\begin{array}{c}(n=467) \\
n(\%)\end{array}$ & $\begin{array}{c}(n=599) \\
n(\%)\end{array}$ & $\begin{array}{c}(n=852) \\
n(\%)\end{array}$ & $\begin{array}{c}(n=4009) \\
n(\%)\end{array}$ \\
\hline Long-term diseases & $53(10.0)$ & $76(11.2)$ & $127(14.4)$ & $40(8.6)$ & $55(9.2)$ & $105(12.3)$ & $456(11.4)$ \\
\hline Allergy & $15(2.8)$ & $26(3.8)$ & $49(5.6)$ & $16(3.4)$ & $16(2.7)$ & $44(5.2)$ & $166(4.1)$ \\
\hline Asthma & $16(3.0)$ & $36(5.3)$ & $42(4.8)$ & $7(1.5)$ & $16(2.7)$ & $35(4.1)$ & $152(3.8)$ \\
\hline Atopy & $22(4.1)$ & $19(2.8)$ & $20(2.3)$ & $17(3.6)$ & $25(4.2)$ & $14(1.6)$ & $117(2.9)$ \\
\hline Migraine & $0(0)$ & $0(0)$ & $12(1.4)$ & $0(0)$ & $3(0.5)$ & $9(1.1)$ & $24(0.6)$ \\
\hline $\mathrm{ADHD}$ & $0(0)$ & $3(0.4)$ & $17(1.9)$ & $0(0)$ & $0(0)$ & $2(0.2)$ & $22(0.5)$ \\
\hline Diabetes & $0(0)$ & $2(0.3)$ & $4(0.5)$ & $2(0.4)$ & $0(0)$ & $9(1.1)$ & $17(0.4)$ \\
\hline Heart defect & $5(0.9)$ & $3(0.4)$ & $5(0.6)$ & $3(0.6)$ & $1(0.2)$ & $3(0.4)$ & $20(0.5)$ \\
\hline Epilepsy & $1(0.2)$ & $3(0.4)$ & $2(0.2)$ & $1(0.2)$ & $3(0.5)$ & $2(0.2)$ & $12(0.3)$ \\
\hline Lactose intolerance & $0(0)$ & $2(0.3)$ & $2(0.2)$ & $0(0)$ & $2(0.3)$ & $3(0.4)$ & $9(0.2)$ \\
\hline Rheumatoid arthritis & $0(0)$ & $1(0.2)$ & $0(0)$ & $0(0)$ & $0(0)$ & $5(0.6)$ & $6(0.1)$ \\
\hline Celiac disease & $1(0.2)$ & $0(0.2)$ & $2(0.2)$ & $0(0)$ & $1(0.2)$ & $1(0.1)$ & $5(0.1)$ \\
\hline Impairments & $5(0.9)$ & $19(2.8)$ & $34(3.9)$ & $2(0.4)$ & $4(0.7)$ & $24(2.8)$ & $88(2.2)$ \\
\hline Visual impairment/heterotropia & $2(0.4)$ & $6(0.9)$ & $3(0.3)$ & $1(0.2)$ & $3(0.5)$ & $7(0.8)$ & $22(0.5)$ \\
\hline Dysphasia & $0(0)$ & $7(1.0)$ & $11(1.3)$ & $0(0)$ & $0(0)$ & $4(0.5)$ & $22(0.5)$ \\
\hline Mentally disabled & $2(0.4)$ & $3(0.4)$ & $7(0.8)$ & $1(0.2)$ & $0(0)$ & $3(0.4)$ & $16(0.4)$ \\
\hline Hearing impairment & $0(0)$ & $0(0)$ & $3(0.3)$ & $0(0)$ & $0(0)$ & $1(0.1)$ & $4(<0.1)$ \\
\hline Other impairment* & $1(0.2)$ & $5(0.7)$ & $14(1.6)$ & $0(0)$ & $1(0.2)$ & $10(1.2)$ & $31(0.8)$ \\
\hline Other diseases & $60(11.3)$ & $36(5.3)$ & $49(5.6)$ & $27(5.8)$ & $33(5.5)$ & $41(4.8)$ & $246(6.1)$ \\
\hline Otitis & $28(5.3)$ & $10(1.5)$ & $4(0.5)$ & $14(3.0)$ & $10(1.2)$ & $3(0.4)$ & $69(1.7)$ \\
\hline Other infection $\neq$ & $10(1.9)$ & $6(0.9)$ & $9(1.0)$ & $5(1.1)$ & $5(0.8)$ & $6(0.7)$ & $41(1.0)$ \\
\hline Urticaria/other skin rash & $1(0.2)$ & $2(0.3)$ & $4(0.5)$ & $1(0.2)$ & $2(0.3)$ & $4(0.5)$ & $14(0.3)$ \\
\hline Common cold & $5(0.9)$ & $0(0)$ & $0(0)$ & $1(0.2)$ & $3(0.5)$ & $1(0.1)$ & $10(0.2)$ \\
\hline Othert & $26(4.9)$ & $20(2.9)$ & $34(3.9)$ & $10(2.1)$ & $15(2.5)$ & $28(3.3)$ & $118(2.9)$ \\
\hline
\end{tabular}

*including autism ¥including other respiratory tract infections tincluding other diseases diagnosed by a physician, e.g., varicella.

household net income per month were not associated with any of the health variables of the child, whereas working status was associated with poor health status and the prevalence of psychosomatic symptoms. Poor health status was most commonly reported for children aged $0-2$ years (7\%), and psychosomatic symptoms for children aged $0-2(13 \%)$ and $7-11$ years (12\%). In contrast, the prevalence of long-term diseases increased with age, being most common among children aged 711 years (13\%). Poor health status and psychosomatic symptoms were more common among children whose parent was not working ( $4 \%$ for poor health status, and $13 \%$ for psychosomatic symptoms) compared with those whose parent was working (3\% and 10\%, respectively).

Only age was significantly associated with poor health, psychosomatic symptoms and the prevalence of longterm diseases in the multivariate analysis when adjusted for other variables (Table 4). The ORs for poor health were lower among children aged 3-6 (OR 0.35, CI $0.20-0.61$ ) and $7-11$ years (OR 0.33, CI 0.20-0.57), and the ORs for psychosomatic symptoms were lower among 3-6-year-old children (OR 0.53, CI 0.39-0.72) compared with children aged 0-2 years. In contrast, the ORs for long-term diseases were highest among 7-11year-old children (OR 1.67, CI 1.24-2.23).

\section{Discussion}

The majority of the children were reported by their parent to have good health. Approximately one tenth had experienced a psychosomatic symptom, or had a longterm disease, most commonly allergies or asthma. Allergies and asthma were also the most common long-term diseases among children reported in earlier studies conducted in Finland $[3,20]$, and are among the most frequently reported long-term diseases also internationally $[13,17,19]$. In contrast to most previous studies, we found that parental socioeconomic factors were not associated with the health of Finnish children aged under 12 years.

Some of the findings concerning the association of children's health and socioeconomic factors which contradict those reported in the literature may be due to the different methodologies used in the studies. One of 
Table 3 Characteristics of the study population $(n=4,032)$

\begin{tabular}{|c|c|c|c|c|c|c|c|c|}
\hline & $\begin{array}{l}\text { Characteristics of the } \\
\text { study population }\end{array}$ & $\begin{array}{l}\text { Health } \\
\text { status }\end{array}$ & & & $\begin{array}{l}\text { Prevalence of } \\
\text { psychosomatic } \\
\text { symptom(s) }\end{array}$ & & $\begin{array}{l}\text { Prevalence of long- } \\
\text { term disease(s) }\end{array}$ & \\
\hline & & Good & $\begin{array}{l}\text { Moderate } \\
\text { or poor }\end{array}$ & & & & & \\
\hline & n (\%) & n (\%) & n (\%) & $\mathrm{p}^{*}$ & n (\%) & $\mathrm{p}^{*}$ & n (\%) & $\mathrm{p}^{*}$ \\
\hline Gender & & & & 0.81 & & 0.45 & & 0.07 \\
\hline Boy & $2106(52)$ & $\begin{array}{c}2023 \\
(97)\end{array}$ & $69(3)$ & & $220(11)$ & & $256(12)$ & \\
\hline Girl & $1926(48)$ & $\begin{array}{l}1857 \\
(97)\end{array}$ & $66(3)$ & & $217(11)$ & & $200(10)$ & \\
\hline Age & & & & 0.00 & & 0.00 & & 0.00 \\
\hline $0-2$ & $1004(25)$ & $932(94)$ & $65(7)$ & & $133(13)$ & & $93(9)$ & \\
\hline $3-6$ & $1287(32)$ & $\begin{array}{l}1256 \\
(98)\end{array}$ & $28(2)$ & & $97(8)$ & & $131(10)$ & \\
\hline $7-11$ & $1741(43)$ & $\begin{array}{l}1692 \\
(98)\end{array}$ & $42(2)$ & & $207(12)$ & & $232(13)$ & \\
\hline $\begin{array}{l}\text { Parent's highest level of } \\
\text { education }\end{array}$ & & & & 0.80 & & 0.89 & & 0.21 \\
\hline $\begin{array}{l}\text { Junior high school or less } \\
\text { ( } \leq 9 \text { years) }\end{array}$ & $252(6)$ & $244(97)$ & $7(3)$ & & $29(12)$ & & $23(9)$ & \\
\hline $\begin{array}{l}\text { Senior high school/ } \\
\text { vocational school (11-13 } \\
\text { years) }\end{array}$ & $2456(61)$ & $\begin{array}{r}2365 \\
(97)\end{array}$ & $85(4)$ & & $265(11)$ & & $269(11)$ & \\
\hline $\begin{array}{l}\text { Polytechnic, college or } \\
\text { university degree ( } \geq 15 \\
\text { years) }\end{array}$ & 1291 (32) & $\begin{array}{l}1240 \\
(97)\end{array}$ & $41(3)$ & & $137(11)$ & & $161(13)$ & \\
\hline $\begin{array}{l}\text { Household's net income/ } \\
\text { month }(€)\end{array}$ & & & & 0.55 & & 0.05 & & 0.60 \\
\hline Below 1999 & $797(20)$ & 766 (96) & $30(4)$ & & $101(13)$ & & $93(12)$ & \\
\hline 2000-2999 & $1292(32)$ & $\begin{array}{l}1243 \\
(97)\end{array}$ & $45(4)$ & & $151(12)$ & & $134(10)$ & \\
\hline 3000-3999 & 1419 (35) & $\begin{array}{l}1372 \\
(97)\end{array}$ & $39(3)$ & & $131(9)$ & & $170(12)$ & \\
\hline $4000-10,000$ & $347(9)$ & $336(97)$ & $10(3)$ & & $35(10)$ & & $38(11)$ & \\
\hline Working status & & & & 0.04 & & 0.01 & & 0.06 \\
\hline Working & $2541(63)$ & $\begin{array}{c}2460 \\
(97)\end{array}$ & $73(3)$ & & $248(10)$ & & $305(12)$ & \\
\hline Not in work & $1470(37)$ & $\begin{array}{c}1402 \\
(96)\end{array}$ & $60(4)$ & & $185(13)$ & & $148(10)$ & \\
\hline
\end{tabular}

* $p$-value of $\leq 0.05$ considered statistically significant.

the reasons for these differences may be that most of the studies included children under 18 years of age as one homogenous group $[11,14,16,18-20]$, and thus it is difficult to estimate whether there are differences in the association with parental socioeconomic background and children's health at different ages. Our results may suggest that parental socioeconomic status is a more important determinant of health in adolescence than in childhood, and that in childhood the effect of parental socioeconomic background on children's health may still be prevented. Prenatal care, child welfare clinics, and school health care where children's health is monitored regularly in Finland, are likely to have a positive effect on their health. This hypothesis is supported by the findings from a previous study in Finland, which found only a minor increase in the prevalence of long-term diseases among children with highly educated mothers [20]. The impact of health care on children's health was, however, not the focus of our study, which remains an important topic for further studies.

The relationship between socioeconomic factors and children's health has been widely studied. However, the social environment, family atmosphere, and relationships with parents and friends may also have an important impact on the health of children [19,29]. For example, poor relationships with parents and friends and poor parental mental health have been found to predict poor health of children. Experiencing warmth and control from mothers has been found to improve children's health [14]. Furthermore, this has been found to be 
Table 4 Logistic regression model of poor health status among children $(n=4032)$, psychosomatic symptoms and long-term diseasest

\begin{tabular}{|c|c|c|c|}
\hline Variable & $\begin{array}{l}\text { Moderate or poor health status } \\
\text { OR }(\mathrm{Cl} 95 \%)\end{array}$ & $\begin{array}{c}\text { Psychosomatic symptoms } \\
\text { OR (Cl 95\%) }\end{array}$ & $\begin{array}{c}\text { Long-term diseases } \\
\text { OR (Cl 95\%) }\end{array}$ \\
\hline \multicolumn{4}{|l|}{ Child } \\
\hline \multicolumn{4}{|l|}{ Gender } \\
\hline Girl & 1.00 & 1.00 & 1.00 \\
\hline Boy & $0.90(0.59-1.37)$ & $0.92(0.74-1.14)$ & $1.23(1.00-1.514)$ \\
\hline \multicolumn{4}{|l|}{ Age, years } \\
\hline $0-2$ & 1.00 & 1.00 & 1.00 \\
\hline $3-6$ & $0.35(0.20-0.61)$ & $0.53(0.39-0.72)$ & $1.22(0.90-1.66)$ \\
\hline $7-11$ & $0.33(0.20-0.57)$ & $0.93(0.71-1.23)$ & $1.67(1.24-2.23)$ \\
\hline \multicolumn{4}{|l|}{ Parent } \\
\hline \multicolumn{4}{|l|}{ Parent's highest level of education } \\
\hline Polytechnic, college or university degree ( $\geq 15$ years) & 1.00 & 1.00 & 1.00 \\
\hline Senior high school/vocational school (11-13 years) & $1.23(0.76-1.98)$ & $1.07(0.83-1.37)$ & $0.78(0.62-0.98)$ \\
\hline Junior high school or less ( $\leq 9$ years) & $0.89(0.32-2.50)$ & $1.16(0.72-1.85)$ & $0.63(0.38-1.04)$ \\
\hline \multicolumn{4}{|l|}{ Household's net income/month $(€)$} \\
\hline 4000-10, 000 & 1.00 & 1.00 & 1.00 \\
\hline 3000-3999 & $0.88(0.38-2.06)$ & $0.78(0.52-1.19)$ & $1.26(0.85-1.86)$ \\
\hline 2000-2999 & $1.32(0.57-3.10)$ & $0.97(0.63-1.48)$ & $1.12(0.74-1.69)$ \\
\hline Below 1999 & $1.42(0.58-3.49)$ & $0.98(0.62-1.54)$ & $1.25(0.81-1.94)$ \\
\hline \multicolumn{4}{|l|}{ Working status } \\
\hline Working & 1.00 & 1.00 & 1.00 \\
\hline Not in work & $0.77(0.48-1.22)$ & $1.22(0.96-1.56)$ & $0.88(0.69-1.12)$ \\
\hline
\end{tabular}

†Adjusted for number of long-term diseases, prevalence of impairments, prevalence of other diseases, the number of psychosomatic symptoms, and the number of other symptoms.

closely connected with parental socioeconomic status; mothers with high income who are highly educated have been shown to have greater abilities to control and give warmth to a child than mothers with low income or less education. Furthermore, one study showed that the relationship between family poverty and depressive symptoms among children were mostly explained by the family environment (poor parental support, divorce or separation) [35]. The parents in our study were mostly well educated and had a good income, and the majority were working, which may explain partly why we did not find an association between parental socioeconomic background and the health of the children.

Our study describes the health of a representative sample of Finnish children aged less than 12 years from three dimensions: self-rated health by the parent, the prevalence of long-term diseases, and psychosomatic symptoms. It was not possible to determine the parental socioeconomic factors among the non-respondents, which is one of the limitations of our study. In addition, there are some distinctions in the definitions of long-term diseases and psychosomatic symptoms between previous studies and our study, which may affect the comparison of the results. For example, we were not able to estimate the severity of longterm diseases or psychosomatic symptoms, as has been done in two previous studies in Nordic countries [10,11]. Our study focused on the association with parental socioeconomic background and children's health. Further studies are needed to explore how different environmental factors, such as family structure, family relations and nutrition, are associated with socioeconomic background and children's health in Finland.

\section{Conclusions}

Most of the Finnish children under 12 years of age were reported by their parent to have good health, and approximately one tenth had experienced psychosomatic symptoms or long-term diseases. In contrast to most previous studies, our study found that parental socioeconomic status is not associated with the health of Finnish children aged less than 12 years. The results may indicate that at this age, the effect of low parental socioeconomic background on children's health may still be prevented.

\section{Additional material}

Additional file 1: Survey questionnaire. Original questionnaire used in the study in Finnish

Additional file 2: Survey questionnaire Original questionnaire used in the study, translated into English 


\section{Acknowledgements and funding}

This study received no specific grant from any funding agency in the public, commercial, or not-for-profit sectors. The study was conducted by the School of Pharmacy/Social Pharmacy, University of Eastern Finland, Kuopio, Finland. All the costs were covered by the School of Pharmacy. Preliminary results have been presented in a poster presentation in the International Social Pharmacy Workshop in Lisbon, 23-26.8.2010.

\section{Author details}

${ }^{1}$ School of Pharmacy/Social Pharmacy, University of Eastern Finland, P.O. Box 1627, FIN-70211 Kuopio, Finland. ${ }^{2}$ Finnish Medicines Agency, Microkatu 1, Kuopio, P.O Box 55, Fl-00301 Helsinki, Finland.

\section{Authors' contributions}

SS drafted the manuscript and participated in the acquisition, analysis and interpretation of the data. RA and $\mathrm{KH}-\mathrm{A}$ have made substantial contributions to the conception, design and acquisition the data, and designing and revising the manuscript. PS has been involved in designing and revising the manuscript. All authors have read and approved the final manuscript.

\section{Competing interests}

The authors declare that they have no competing interests.

Received: 17 November 2010 Accepted: 9 June 2011

Published: 9 June 2011

\section{References}

1. World Health Organization (WHO): Health 21. The health for all policy framework for the WHO European Region. European Health for All Series No 6 World Health Organization Regional Office for Europe Copenhagen 1999 [http://www.euro.who.int/_data/assets/pdf_file/0010/98398/ wa540ga199heeng.pdf].

2. Marmot M: Social determinants of health inequalities. Lancet 2005, 365:1099-1104.

3. Arinen S, Häkkinen U, Klaukka T, Klavus J, Lehtonen R, Aro S: Health and the Use of Health Services in Finland: main findings of the Finnish Health Care Survey 1995/96 and changes from 1987. Stakes and Kela, SVT Health Care Helsinki 1998

4. Ministry of Social Affairs, Health (Sosiaali- ja Terveysministeriö): Valtioneuvoston periaatepäätös Terveys 2015-kansanterveysohjelmasta. Sosiaali- ja terveysministeriön julkaisuja 2001, 4, Helsinki 2001.

5. Kunst AE, Bos V, Lahelma E, Bartley M, Lissau I, Regidor E, Mielck A, Cardano M, Dalstra JAA, Geurts JJM, Helmert U, Lennartsson C, Ramm J, Spadea T, Stronegger WJ, Mackenbach JP: Trends in socioeconomic inequalities in self-assessed health in 10 European countries. Int $\mathrm{J}$ Epidemiol 2005, 34:295-305.

6. Mackenbach JP, Martikainen P, Looman CWN, Dalstra JAA, Kunst AE, Lahelma $E$, members of the SEdHA working group: The shape of the relationship between income and self-assessed health: an international study. Int J Epidemiol 2005, 34:286-293.

7. Palosuo H, Koskinen S, Lahelma E, Prättälä R, Martelin T, Ostamo A, Keskimäki I, Sihto M, Talala K, Hyvönen E, Linnanmäki E: Terveyden eriarvoisuus Suomessa sosioekonomisten terveyserojen muutokset 19802005. Sosiaali- ja terveysministeriön julkaisuja 2007, 23.

8. Mackenbach JP, Stirbu I, Roskam AR, Schaap MM, Menvielle G, Leinsalu M, Kunst $A E$, for the European Union working Group in Socioeconomic Inequalities in Health: Socioeconomic Inequalities in Health in 22 European Countries. N Engl J Med 2008, 358:2468-2481.

9. Pärna K, Ringmets $\mathrm{l}$ : Comparison of socioeconomic differences in selfperceived health in Estonia and Finland. Scand J Public Health 2010, 38:129-134.

10. Halldórsson M, Kunst AE, Köhler L, Mackenbach J: Socioeconomic inequalities in the health of children and adolescents. A comparative study of the five Nordic countries. Eur J Public Health 2000, 10(4):281-288.

11. Berntsson $L T$, Köhler L: Long-term illness and psychosomatic complaints in children aged 2-17 years in the five Nordic countries. Eur J Public Health 11(1):35-42

12. Pedersen C, Madsen M: Parents'labour market participation as a predictor of children's health and wellbeing: a comparative study in five Nordic countries. J Epidemiol Community Health 2002, 56:861-867.

13. Emerson $E$, Graham $H$, Hatton $C$ : Household income and health status in children and adolescents in Britain. Eur J Public Health 2005, 16:354-360.
14. Bauman L, Silver EJ, Stein REK: Cumulative Social Disadvantage and Child Health. Pediatrics 2006, 117(4):1321-1328.

15. Belsky J, Bell B, Bradley RH, Stallard N, Stewart-Brown SL: Socioeconomic risk, parenting during the preschool years and child health age 6 years. Eur J Public Health 2006, 17(5):508-513.

16. Chen E, Martin AD, Matthews KA: Socioeconomic status and health: Do gradients differ within childhood and adolescence? Soc Sci Med 2006, 62:2161-2170.

17. Currie A, Shields MA, Price SW: The child health/family income gradient: Evidence from England. J Health Econ 2007, 26:213-232.

18. Larson K, Russ SA, Crall JJ, Halfon N: Influence of Multiple Social Risks on Children's Health. Pediatrics 2008, 121:337-344

19. Victorino CC, Gauthier AH: The social determinants of child health: variations across health outcomes- a population-based cross-sectional analysis. BMC Pediatrics 2009, 9:53.

20. Najman JM, Hayatbakhsh MR, Clavarino A, Bor W, O'Callaghan MJ, Williams GM: Family Poverty Over the Early Life Course and Recurrent Adolescent and Young Adult Anxiety and Depression: A Longitudinal Study. Am J Public Health 2010, 100(9):1719-1723.

21. Alaimo K, Olson CM, Frongillo EA, Briefel RR: Food Insufficiency, Family Income, and Health in US Preschool and School-Aged Children. Am J Public Health 2001, 91(5):781-786.

22. Kroenke C: Socioeconomic status and health: Youth development and neomaterialist and psychosocial mechanisms. Soc Sci Med 2008, 66:31-42.

23. Rose-Jacobs R, Black MM, Casey PH, Cook JT, Cutts DB, Chilton M, Heeren T, Levenson SM, Meyers AF, Frank DA: Household Food Insecurity: Association With At-Risk Infant and Toddler Development. Pediatrics 2008, 121:65-72.

24. Takala P, Klaukka T, Rahkonen O: Astma ja allergia selittävät lasten pitkäaikaissairastavuuden lisääntymisen. Suom Laakaril 2001, 41(56):4151-4155.

25. Prel X, Krämer U, Behrendt H, Ring J, Oppermann H, Schikowski T, Ranft U: Preschool children's health and its association with parental education and individual living conditions in East and West Germany. BMC Public Health 2006, 6:312.

26. West $\mathrm{P}$, Sweeting $\mathrm{H}$ : Evidence on equalization in youth from the West of Scotland. Soc Sci Med 2004, 59:13-27.

27. Kestilä L, Koskinen S, Martelin T, Rahkonen O, Pensola T, Aro H, Aromaa A: Determinants of health in early adulthood: what is the role of parental education, childhood adversities and own education? Eur J Public Health 2005, 16(3):305-314.

28. Melchior M, Moffitt TE, Milne BJ, Poulton R, Caspi A: Why Do Children from Socioeconomically Disadvantaged Families Suffer from Poor Health When They Reach Adulthood. A life-Course Study Am J Epidemiol 2007 , 166(8):966-974.

29. Due P, Lynch J, Holstein B, Modvig J: Socioeconomic health inequalities among a nationally representative sample of Danish adolescents: the role of different types of social relations. J Epidemiol Community Health 2003, 57:692-698.

30. Perhevapaat. [http://www.mol.fi/mol/fi/02_tyosuhteet_ja_lait/ 011_tyosopimus/06_perhevapaat/index.jsp].

31. Klaukka T, Martikainen J, Kalimo E: Drug Utilization in Finland 1964-1987. Publications of the Social Insurance Institution, Helsinki 1990.

32. National Institute for Health and Welfare: School Health Promotion Study. [http://info.stakes.fi/kouluterveyskysely/EN/index.htm].

33. Hämeen-Anttila K, Lindell-Osuagwu L, Sepponen K, Vainio K, Halonen P, Ahonen R: Factors associated with medicine use among children aged under 12 years- a population survey in Finland. Pharmacoepidemiol Drug Saf 2009, 19(4):400-407.

34. Ylinen S, Hämeen-Anttila K, Sepponen K, Kettis Lindblad A, Ahonen R: The use of prescription medicines and self-medication among children- a population-based study in Finland. Pharmacoepidemiol Drug Saf 2010, 19:1-9.

35. Tracy M, Zimmerman FJ, Galea S, McCauley E, Vander Stoep A: What explains the relation between family poverty and childhood depressive symptoms? J Psychiatr Res 2008, 42:1163-1175.

\section{Pre-publication history}

The pre-publication history for this paper can be accessed here: http://www.biomedcentral.com/1471-2458/11/457/prepub

doi:10.1186/1471-2458-11-457

Cite this article as: Siponen et al: Children's health and parental socioeconomic factors: a population-based survey in Finland. BMC Public Health 2011 11:457. 